\title{
Analisis perwatakan tokoh utama dalam novel Negeri 5 Menara karya Ahmad Fuadi (psikologi sastra) dan kontribusinya dalam pembelajaran sastra di MTs Parang Magetan
}

\author{
Hartini ${ }^{1}$, Satrijo Budi Wibowo ${ }^{2}$ \\ 1,2) Universitas PGRI Madiun, JI. Setiabudi No. 85 Madiun \\ e-mail: ${ }^{1)}$ hartiniparang@gmail.com; ${ }^{2)}$ satrijo@unipma.ac.id
}

\begin{abstract}
Abstrak
Penelitian ini bertujuan untuk mendeskripsikan perwatakan tokoh utama dalam novel Negeri 5 Menara karya Ahmad Fuadi dan kontribusinya terhadap pembelajaran sastra di MTs Parang Magetan.Metode penelitian yang digunakan adalah metode kualitatif deskriptif. Teknik pengumpulan data dalam penelitian ini yaitu dokumen. Penelitian ini menggunakan transkrip monolog atau percakapan tokoh utama dalam novel Negeri 5 Menara karya Ahmad Fuadi, bahan kepustakaan berupa buku-buku teori penunjang penelitian dan jurnal penelitian. Teknik analisis data yang digunakan adalah analisis isi, yaitu dengan mengidentifikasi data, mengklasifikasi data, analisis datadan kontribusi hasil penelitian. Hasil penelitian menunjukkan bahwa perwatakan tokoh utama dalam novel Negeri 5 Menara mencakup ramah, ragu-ragu, bertanggungjawab, egois, percaya diri, optimis, pantang menyerah, dan solidaritas.Kontribusi hasil penelitian terhadap pembelajaran sastra di MTs Parang Magetan adalah novel yang digunakan peneliti dapat digunakan untuk pembelajaran membaca karya sastra di sekolah.Hasil penelitian dapat digunakan untuk penggambaran perwatakan seorang remaja yang masih terpengaruh oleh Id, Ego, dan Superego.
\end{abstract}

Kata kunci: perwatakan, tokoh utama, novel, psikologi sastra

\section{The analysis of main character in Ahmad Fuadi's novel Negeri 5 Menara (literature psychology) and its contributions on literary learning at MTs Parang Magetan}

\begin{abstract}
This study aims to describe the main character in Ahmad Fuadi's novel Negeri 5 Menaraand its contribution in literary learning at MTs Parang Magetan. The research method used was descriptive qualitative method. Technique of collecting data in this research was documentation. This research used transcripts of monologue or conversation of the main character in Ahmad Fuadi's novel Negeri 5 Menara, and references taking from books and research journals. Data analysis technique used wascontent analysisby identifying data, classifying data, data analysis and showing the contribution of research results. The result reveals that the main character in the novel Negeri 5 Menara is friendly, hesitant, responsible, selfish, confident, optimistic, unyielding, and solidarity. The contribution of the teaching literature at MTs Parang Magetan is that novel can be used a product read as a literary work in Junior high school. The results describes the character of a teenager who is still affected by $I d$, Ego, and Superego.
\end{abstract}

Keywords: characterization, main character, novel, literature psychology 


\section{Pendahuluan}

Layaknya dalam kehidupan sehari-hari penggambaran tokoh dalam novel dapat diceritakan secara rinci oleh pengarang. Pengarang yang baik dapat menggambarkan tokoh dalam cerita secara tersirat. Pembaca harus mencari sendiri penggambaran watak setiap tokoh dalam cerita. Penggambaran setiap tokoh dalam cerita dapat dipengaruhi oleh konteks yang ada dalam cerita. Ketika cerita dalam novel berada dalam susasana yang mencekam maka dapat digambarkan tokoh tersebut mengalami sebuah gejolak. Tokoh yang digambarkan dalam sebuah cerita membawa pengaruh besar terhadap cerita yang ditulis oleh pengarang.

Nurgiyantoro (2012: 190) menyatakan bahwa berdasarkan kemungkinan pencerminan tokoh cerita terhadap (sekelompok) manusia dari kehidupan nyata, tokoh cerita dibedakan menjadi tokoh tipikal (typical character) dan tokoh netral (neutral character). tokoh netral dapat dijadikan tokoh utama dalam suatu cerita. Tokoh netral dapat menjadi tokoh yang bulat di dalam cerita. Cerita yang ditulis oleh seorang pengarang dapat berupa cerita fiksi atau rekaaan. Cerita rekaan adalah cerita yang digambarkan dalam kehidupan sehari-hari. Cerita rekaan memiliki tokoh dan alur cerita yang mirip dengan kehidupan sehari-hari masyarakat. Stanton (dalam Hastuti, 2008: 17) yang menyatakan bahwa fiksi adalah kehidupan, sedangkan kehidupan adalah permainan yangpaling menarik.

Sebuah karya sastra tidak dapat dijauhkan dengan penggambaran perwatakan tokoh dalam cerita. Minderop (2011: 95) menyatakan bahwa perwatakan adalah kualitas nalar dan perasaan para tokoh di dalam suatu karya fiksi yang dapat mencakup tidak saja tingkah laku atau tabiat dan kebiasaan, tetapi juga penampilan. Adanya perwatakan tokoh memberikan penggambaran cerita yang jelas. Penggambaran perwatakan tokoh dalam karya sastra tidak jauh berbeda dengan kehidupan sehari-hari. Pengarang menggambarkan tokoh dengan perwatakan yang didasarkan dengan fiksi ataupun kenyataan yang ada. Penggambaran perwatakan secara tidak langsung dapat dikaitkan dalam pembelajaran sastra.

Pembelajaran sastra di sekolah khususnya memberikan gambaran perwatakan

yang dihadapi dalam kehidupan nyata secara sosial maupun individual. Penggambaran yang ada dalam novel negeri 5 menara merupakan salah satu wujud kehidupan pesantren dengan perwatakan tokoh yang berbeda.

Perwatakan tokoh dalam novel "Negeri 5 Menara" dapat dianalisis menggunakan kajian psikologi sastra. Minderop (2011: 54) yang menyatakan bahwa psikologi sastra adalah telaah karya sastra yang diyakini mencerminkan proses dan aktivitas kejiwaan. Perwatakan yang digambarkan dalam novel tersebut berkaitan dengan ketidakstabilan emosi dari tokoh utama. Tokoh utama yang digambarkan masih berada diusia peralihan dari masa pubertas sehingga emosi tokoh utama berpengaruh terhadap watak yang dimiliki. Nurgiyantoro (2012: 177) menyatakan bahwa tokoh utama adalah tokoh yang diutamakan penceritaannya dalam novel yang bersangkutan. Oleh karena itu novel menjadi objek kajian peneliti untuk dianalisis perwatakan tokoh utama.

Peneliti menganalisis perwatakan tokoh utama dan kontribusinya dalam pembelajaran sastra di sekolah MTs. Penggunaan novel negeri 5 menara merupakan objek yang pas dikarenakan kesesuaian isi novel tentang kehidupan pesantren dan sekolah MTs sebagai kontribusi hasil penelitian. Oleh karena itu peneliti menganalisi novel negeri 5 menara dan hasil penelitian peneliti dikontribusikan pada pembelajaran sastra di MTs.

Nurgiyantoro (2012: 165) menyatakan bahwa character dapat berarti 'pelaku cerita' dan dapat pula berarti 'perwatakan'. Pendapat lain dikemukakan oleh Minderop (2011: 95) menyatakan bahwa perwatakan adalah kualitas nalar dan perasaan para tokoh di dalam suatu karya fiksi yang dapat mencakup tidak saja tingkah laku atau tabiat dan kebiasaan, tetapi juga penampilan. Perwatakan berhubungan dengan

Linguista Vol. 1, No. 1, Juni 2017: 1 -5 
karakteristik atau bagaimana watak tokoh-tokoh itu, sedangkan penokohan berhubungan dengan cara pengarang menentukan dan memilih tokoh-tokohnya serta memberi nama tokoh itu (Waluyo, 2002: 164).

Nurgiyantoro (2012: 178) menyatakan bahwa tokoh utama (central character, main character). Tokoh utama adalah tokoh yang diutamakan penceritaannya dalam fiksi. Tokoh utama merupakan tokoh yang paling banyak diceritakan, baik sebagai pelaku kejadian maupun yang dikenai kejadian. Tokoh utama umumnya merupakan tokoh yang sering diberi komentar dan dibicarakan oleh pengarangnya. Tokoh yang namanya diangkat sebagai judul cerita merupakan tokoh utama (Aminuddin, 1987: 80).

Waluyo (2002: 168) menyatakan bahwa tokoh sentral atau tokoh utama adalah tokoh yang mendominasi jalannya cerita rekaan. Biasanya terdiri atas tokoh protagonis dan antagonis. Tokoh protagonis adalah tokoh sentral atau tokoh yang mendukung jalannya cerita, sedangkan tokoh antagonis adalah tokoh yang mempunyai konflik dengan tokoh protagonis.

Nurgiyantoro (2012: 11) yang menyatakan bahwa novel adalah karya sastra yang dapat mengemukakan sesuatu secara bebas, menyajikan sesuatu secara lebih banyak, lebih rinci, lebih detail dan lebih banyak melibatkan berbagai permasalahan yang lebih kompleks. Hal itu mencakup berbagai unsur cerita yang membangun novel tersebut.

Minderop (2011: 54) yang menyatakan bahwa psikologi sastra adalah telaah karya sastra yang diyakini mencerminkan proses dan aktivitas kejiwaan. Psikologi sastra adalah kajian yang mendalam mengenai tingkah laku dan kejiwaan dalam karya sastra. Psikologi sastra juga berkaitan dengan kajian yang mendalam pada konflik batin tokoh-tokoh cerita. Kajian psikologi sastra juga berkaitan dengan kehidupan sosial dan masyarakat manusia.

\section{Metode Penelitian}

Penelitian ini menggunakan pendekatan psikologi sastra dengan jenis realitas (ontologis) yang sesuai dengan objek penelitian. Endaswara (dalam Minderop, 2011: 59) yang menyatakan bahwa psikologi sastra adalah sebuah interdisiplin antara psikologi dan sastra. Jenis penelitian yang digunakan adalah penelitian kualitatif deskriptif. Sutopo (2002: 111) menyebutkan bahwa penelitian kualitatif deskriptif mengarah pada pendeskripsian secara rinci dan mendalam mengenai potret kondisi tentang apa yang sebenarnya terjadi menurut apa adanya di lapangan studinya.

Sugiyono (2014: 62) menyatakan bahwa sumber data primer adalah sumber data yang langsung memberikan data kepada pengumpul data. Penelitian ini menggunakan sumber data primer berupa novel Negeri 5 Menara. Sumber data sekunder berupa sumber data yang diproses secara tidak langsung seperti internet, jurnal, skripsi, buku acuan dan lain-lain. Jurnal dan buku acuan digunakan peneliti untuk landasan teori.

Teknik pengumpulan data dalam penelitian ini yaitu Dokumen. Sutopo (2002: 54) yang menyatakan bahwa dokumen dan arsip merupakan bahan tertulis yang bergayutan dengan suatu peristiwa atau aktivitas tertentu. Teknik analisis data yang digunakan adalah analisis isi, yaitu dengan mengidentifikasi data, mengklasifikasi data, analisis data dan kontribusi hasil penelitian. Penelitimenggunakan uji keabsahan data berupa uji kredibilitas data dengan menggunakan metode peningkatan ketekunan.

\section{Hasil dan Pembahasan}

\section{Bertanggung jawab}

Kemdiknas (2010: 15) menyatakan bahwa tanggung jawab adalah sikap dan perilaku seseorang untuk melaksanakan tugas dan kewajibannya yang seharusnya dia lakukan terhadap diri sendiri, masyarakat, lingkungan (alam, sosial dan budaya), negara dan Tuhan yang Maha Esa. Tokoh utama dalam novel Negeri 5 Menara yaitu 
Alif Fikri yang digambarkan seorang siswa pondok pesantren yang baru masuk. la digambarkan belum dapat beradaptasi dengan lingkungan yang penuh dengan kedisiplinan termasuk waktu. Awal masuk ia mendapat hukuman dikarenakan terlambat untuk berangkat ke masjid. Namun setelah mendapat hukuman ia mulai bertanggung jawab dengan setiap kewajiban yang sudah dituliskan dalam peraturan pondok.

\section{Bersahabat}

Kemdiknas (2010: 15) menyatakan bahwa bersahabat atau komunikatif artinya tindakan yang memperlihatkan rasa senang berbicara, bergaul dan bekerjasama dengan orang lain. Alif dikenal dengan pemuda yang berasal dari Bukittinggi. Alif belum pernah mengenal orang-orang dengan latar belakang yang berbeda dengannya. Ketika ia berada di pondok pesantren ia mulai mengenal berbagai suku di Indonesia dan mulai bersahabat dengan teman seperjuangannya di pondok. Persahabatan mereka berlanjut hingga mereka menemukan kehidupan baru di luar negeri bersama keluarga masing-masing.

\section{Ramah}

Alif juga digambarkan sebagai tokoh yang memiliki keramahan. Alif menyadari ia orang baru dan harus mengenal satu sama lain. Alif mengajak seorang teman yang berasal dari Jakarta untuk berjabat tangan dan saling memperkenalkan diri.

\section{Keraguan}

Kehidupan pesantren yang dirasakan baru untuk Alif membuat ia bimbang. Keseharian Alif masih dibayangi dengan keraguan. Ketika ia mulai menerima pelajaran bahasa asing, Alif masih meragukan kemampuannya untuk berpidato dengan bahasa asing.

\section{Egois}

Pengaruh usia yang masih tergolong dalam masa pubertas membuat tokoh Alif digambarkan sebagai tokoh yang egois. Alif mengalami perdebatan dengan ibunya untuk meneruskan di pondok pesantren. Alif memiliki keinginan untuk meneruskan pendidikan di sekolah menengah atas namun keinginannya tidak dapat diwujudkan. Alif marah dan setengah hati menjalankan perintah ibunya.

\section{Percaya diri}

Tokoh Alif digambarkan memiliki kepercayaan diri tinggi sejak ia masih duduk di MTs. Alif digambarkan memiliki prestasi yang baik hingga ia lulus sekolah. Hingga ia di pondok kini ulai merasakan kepercayaan dirinya meningkat. Ketika Alif ditunjuk untuk menjadi salah satu pembaca pidato di depan tamukehormatan pesantren. Alif pun dengan percaya diri menggunakan gayanya menyampaikan pidato dan disukai oleh semua orang.

\section{Optimis}

Alif melanjutkan pendidikan di pondok yang digambarkan berbeda pulau dengan tempat kelahirannya. Alif yang mulanya setengah hati menjalankan keinginan ibunya kini merasakan kenyamanan untuk melanjutkan pendidikannya. Alif optimis dengan kemampuan yang dimilikinya setelah masuk pondok dan optimis melanjutkan ke perguruan tinggi sesuai dengan cit-citanya.

\section{Pantang Menyerah}

Alif menyadari setiap cita-cita yang ingin dicapai perlu perjuangan yang tidak mudah. Alif merasakan saat berproses dengan sungguh-sungguh maka hasilnya pun 
akan memuaskan. Alif mendapat tugas mencari berita dari seorang panglima TNI terkenal. Alif rela tubuh kecilnya berdesak-desakan dengan wartawan yang sudah senior. Namun usaha Alif tidak sia-sia dan berakhir dengan berita yang berkualitas untuk dibaca warga pondok.

Beberapa perwatakan tokoh utama tersebut dapat dikontribusikan dalam pembelajaran sastra di sekolah MTs. Siswa MTs yang umumnya masih masa-masa pubertas dan memiliki latar belakang sekolah keagamaan. Novel Negeri 5 Menara merupakan novel keagamaan dan menceritakan kehidupan pesantren. Hasil penelitian berupa perwatakan tokoh utama tersebut dapat digunakan siswa siswi sebagai objek dan pembelajaran sehari-hari. Siswa siswi dapat menggunakan novel Negeri 5 Menara sebagai objek gambaran kehidupan pesantren dan tertarik untuk melanjutkan pendidikan di pesantren.

Penelitian yang dilakukan peneliti memiliki perbedaan dengan penelitian Penelitian Handayani (2009) Setiap tokoh digambarkan berbeda dengan karakter masing-masing untuk membangun cerita. Berbeda dengan analisis yang dilakukan oleh peneliti. Peneliti memfokuskan pada perwatakan yang dialami oleh tokoh utama. Meskipun dalam hasil penelitian ada beberapa hasil penelitian yang sama namun novel yang digunakan berbeda.

\section{Kesimpulan}

Perwatakan tokoh utama dalam novel Negeri 5 Menara yaitu ramah, ragu-ragu, bertaggung jawab, egois, percaya diri, optimis, pantang menyerah, dan solidaritas. Keseluruhan perwatakan tokoh dipengaruhi oleh lingkungan dan psikologi dari tokoh. Kehidupan tokoh dengan latar belakang keagamaan yang kental dengan kehidupan pesantren yang dijalani merupakan hal yang saling terkait namun berbanding terbalik dengan keinginan dari tokoh utama.

Semoga hasil penelitian yang dilakukan oleh peneliti dapat digunakan untuk referensi guru bahasa Indonesia sebagai contoh analisis perwatakan tokoh dalam novel. Semoga penelitian ini dapat bermanfaat bagi peneliti lain yang memiliki kajian dan analisis yang sama. Semoga penelitian ini dapat bermanfaat bagi pembaca dan menambah wawasan baru dalam bidang sastra khususnya

\section{Daftar Pustaka}

Aminuddin. (1987). Pengantar Apresiasi Karya Sastra. Malang: Cv. Sinar Baru.

Fuadi, A. (2010). Negeri 5 Menara. Jakarta: PT. Gramedia Pustaka Utama.

Kemendikbud. (2012). Pendidikan Karakter Terintegrasi dalam Pembelajarandi Sekolah Menengah Pertama. Jakarta: Direktorat PSMP Kemdiknas.

Minderop, A. (2011). Metode Karakterisasi Telaah Fiksi. Jakarta: Yayasan Pustaka Obor Indonesia.

Nurgiyantoro, B. (2012). Teori Pengkajian Fiksi. Yogyakarta: Gadjah Mada University Press.

Sugiyono. (2014). Memahami Penelitian Kualitatif. Bandung: CV. Alfabeta.

Sutopo. (2002). Metodologi Penelitian Kualitatif. Surakarta: Sebelas Maret University Press.

Waluyo. Herman J. (2002). Pengkajian Sastra Rekaan. Salatiga: Widya Sari Press Salatiga. 